Canadian

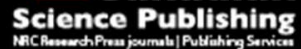

Canadian Journal of Physiology and Pharmacology Revue canadienne de physiologie et pharmacologie

\title{
Distribution pattern of dorsal root ganglion neurons synthesizing nitric oxide synthase in different animal species.
}

\begin{tabular}{|r|l|}
\hline Journal: & Canadian Journal of Physiology and Pharmacology \\
\hline Manuscript ID & cjpp-2016-0294.R2 \\
\hline Manuscript Type: & Review \\
\hline Complete List of Authors: & $\begin{array}{l}\text { Kolesár, Dalibor; Univerzita Pavla Jozefa Safarika v Kosiciach Lekarska } \\
\text { fakulta, Anatomy } \\
\text { Kolesárová, Mária; Univerzita veterinarneho lekarstva a farmacie v } \\
\text { Kosiciach, Pharmacology and toxicology } \\
\text { Kyselovič, Ján; Univerzita Komenskeho v Bratislave, Pharmacology and } \\
\text { toxicology }\end{array}$ \\
\hline Keyword: & $\begin{array}{l}\text { dorsal root ganglia, primary afferent neurons, nitric oxide, nitric oxide } \\
\text { synthase, NADPH diaphorase }\end{array}$ \\
\hline
\end{tabular}

\section{SCHOLARONE}

Manuscripts 
Distribution pattern of dorsal root ganglion neurons synthesizing nitric oxide synthase in different animal species.

Kolesár Dalibor, ${ }^{\mathrm{a}}$ Kolesárová Mária, ${ }^{\mathrm{b}}$ Kyselovič Ján, ${ }^{\mathrm{c}}$

${ }^{\mathrm{a} D e p a r t m e n t ~ o f ~ A n a t o m y, ~ F a c u l t y ~ o f ~ M e d i c i n e, ~ P a v o l ~ J o z e f ~ S ̌ a f a ́ r i k ~ U n i v e r s i t y ~ i n ~ K o s ̌ i c e, ~}$ Slovak Republic

${ }^{\mathrm{b}}$ Institute of Human and clinical Pharmacology, University of Veterinary Medicine and Pharmacology in Košice, Slovak Republic

${ }^{\mathrm{c}}$ Department of Pharmacology and Toxicology, Faculty of Pharmacy, Comenius University in Bratislava, Slovak Republic

Corresponding author:

Dalibor Kolesár M.D., PhD.

Department of Anatomy

Faculty of Medicine

Pavol Jozef Šafárik University

Šrobárova 2

04180 Košice

Slovak Republic

Telephone: $+421055 / 2343215$

Email: dalibor.kolesar@upjs.sk 


\begin{abstract}
The main aim of the present review is to provide at first a little survey of the basic anatomical description of sensory ganglion neurons in relation to cell size, conduction velocity, thickness of myelin sheath and functional classification of their processes. In addition, we have focused to discuss current knowledge about the distribution pattern of neuronal nitric oxide synthase containing sensory neurons especially in the dorsal root ganglia in different animal species, hence, there is a large controversy in relation to interpretation of the results dealing with this interesting field of research.
\end{abstract}

Keywords: sensory ganglia, dorsal root ganglia, primary afferent neurons, nitric oxide, nitric oxide synthase, NADPH diaphorase 


\section{Overview of the sensory ganglia}

The sensory ganglia (SGs) are specialized structures of the peripheral nervous system (PNS) composed of the primary afferent neurons which transmit different types of sensory modalities from the peripheral receptors to the central nervous system (CNS). Sensory information from the limbs and trunk is conveyed by the dorsal root ganglia (DRGs) which are situated near the spinal cord in the course of dorsal roots of the corresponding peripheral spinal nerves. Similarly, the primary afferent neurons innervating region of the head and neck and also some internal organs are situated in the SGs of the corresponding cranial nerves. The largest is the trigeminal ganglion (TG) which belongs to the main sensory nerve of the head the trigeminal nerve. The principal cell type of the majority of SGs are pseudounipolar neurons (sometimes called T-shaped neurons). These neurons possess only one T-shaped axon arising from the cell body which bifurcates after short distance into two processes (axons). The long peripheral axons run to the periphery and innervate various types of sensory receptors while the short central axons arising on the opposite site of ganglion enter the CNS in the dorsal root entry zone (DREZ).

Except of neurons each sensory ganglion contains fibrose tissue, nerve fibers entering and leaving the ganglion and supporting cells which include Schwann cells and satellite glial cells. The primary afferent neurons could be classified according to various morphological, physiological and biochemical characteristics. The most widely used morphological classification of the SG neurons is division into two main groups according to the light microscopic appearance: the neurofilament-rich "large light" cells and the neurofilament-poor "small dark" cells (Lawson et al. 1974; Snider and McMahon 1998). In addition, some authors prefer to divide SG neurons either according to the cross-sectional area of cell body surface or in relation to the cell diameter into three groups: small cells $\left(<1000 \mu \mathrm{m}^{2} ; \leq 20 \mu \mathrm{m}\right)$, medium- 
sized cells (1000-2000 $\left.\mu \mathrm{m}^{2} ; 20-50 \mu \mathrm{m}\right)$, and large-sized cells $\left(>2000 \mu \mathrm{m}^{2} ; \geq 50 \mu \mathrm{m}\right)$, however, different criteria exists also in that type of classification in different animal species.

Another criterion for division of the ganglionic cells is diameter, degree of myelination and conduction velocity of their nerve fibers (Table 1).

A $\alpha$ (Type I) fibers are the thickest $(12-20 \mu \mathrm{m})$, the most myelinated and most rapidly conducting afferent fibers $(70-120 \mathrm{~m} / \mathrm{s})$. Functionally, they are proprioceptors which means they provide sensitivity from the muscle spindles (Ia) and the Golgi tendon organs (Ib). Likewise the $\mathrm{A} \beta$ fibers they originate exclusively from the large ganglionic cells. Upon entering the spinal cord the fibers could terminate in three different manners. The vast majority of them make synapses with the neurons located in the dorsal nucleus of Clark in the medial portion of lamina VII in T1-L3 spinal cord segments. Some of the fibers tend to enter the dorsal funiculus and constitute a portion of the dorsal column-medial lemniscus (DCML) pathway. The least proportion of the fibers terminate directly or after synapsing with interneurons on the ventral horn $\alpha$-motoneurons and thus forming typical monosynaptic Ia stretch-reflex circuit.

$\mathrm{A} \beta$ (Type II) fibers are medium-sized $(6-12 \mu \mathrm{m})$, thickly myelinated with fast conduction velocity ranging from $30-70 \mathrm{~m} / \mathrm{s}$. These fibers arise especially from the large ganglionic cells with diameter over $50 \mu \mathrm{m}$. A $\beta$ fibers are functionally related to the low threshold mechanoreceptors and they are responsive to different kinds of mechanical stimulation e.g. discriminative (fine) touch, pressure, 2-point discrimination and vibration. Just before entering the spinal cord $A \beta$ fibers are situated in the dorsomedial division of the corresponding dorsal roots. After entering the spinal cord the majority of the fibers divide into short descending branch and long ascending branch which in turn send collaterals to several spinal cord segments where they synapse with several distinct groups of the dorsal horn 
interneurons and the ventral horn motoneurons. The ascending branches continue without synapsing in the dorsal horn gray matter in the ipsilateral dorsal funiculus of the spinal cord forming the DCML pathway as far as they reach the dorsal column nuclei (gracile and cuneate nucleus) in the caudal part of the medulla oblongata where they create synapses with the second-order neurons. The fibers of the DCML pathway are topographically organized such that axons running from the lower limbs and lower part of the trunk are situated in the medial portion of the dorsal funiculus forming the fasciculus gracilis and axons innervating upper limbs and upper part of the trunk are situated more laterally creating the fasciculus cuneatus.

A $\delta$ (Type III) fibers are thicker $(2-5 \mu \mathrm{m})$, rapidly conducting $(12-30 \mathrm{~m} / \mathrm{s})$ and poorly myelinated. They arise from the medium-sized neurons with the cell diameter ranging from 30-50 $\mu \mathrm{m}$. These fibers are sensitive to different combinations of temperatures, various types of nociceptive cues and non-discriminative (crude) touch. According to conduction velocity the A $\delta$ fibers are also known as the fibers responsible for perception of accurately localized, short lasting "sharp and fast pain" while C fibers transmit more diffuse, poorly localized, long lasting "dull and slow pain" (Basbaum et al. 2009). After entering the spinal cord A $\delta$ fibers tend to synapse in the superficial dorsal horn lamina I (posteromarginal nucleus) but also in the more deeply situated lamina $\mathrm{V}$ in which they probably mediate nocifensive reflexes.

C fibers (Type IV) are the thinnest $(0.5-1 \mu \mathrm{m})$, the slowest $(0.5-2 \mu \mathrm{m} / \mathrm{s})$ and unmyelinated in relation to axon diameter, conduction velocity and degree of myelination. They are derived from the most abundant small ganglionic cells with diameter ranging from 10-30 $\mu \mathrm{m}$. These fibers are generally considered as high threshold mechanoreceptors, thermoreceptors and polymodal nociceptors. According to chemical content the $\mathrm{C}$ fibers are further subdivided into two main groups: peptidergic and nonpeptidergic (Alvarez et al. 1991). 
The peptidergic fibers arise mainly from the small to medium-sized cells which synthesize substance P (SP) and calcitonin gene-related peptide (CGRP) and they also express high affinity receptor for nerve growth factor (NGF) (Fang et al. 2005). The nonpeptidergic fibers are related to cells which bind histological marker called isolectin B4 (IB4) derived from Griffonia simplicifolia and express receptor for glial cell line-derived neurotrophic factor (GDNF) (Averill et al. 1995; Zwick et al. 2002). However, synthesis of SP and especially CGRP is not restricted only to subpopulation of small neurons. It has been clearly demonstrated that CGRP is expressed also in subpopulation of large cells which are simultaneously immunoreactive for RT97 and NF200 (antibodies directed against neurofilaments) (McCarthy and Lawson 1989, 1990). The peripheral axons of C fibers terminate as the free nerve endings in the different types of peripheral tissues while their central axons enter the spinal cord and bifurcate into an ascending and descending branches running in the dorsolateral tract of Lissauer for distance of 1-3 spinal cord segments. Collaterals of these branches then terminate in the superficial dorsal horn lamina II (substantia gelatinosa) where they synapse with the interneurons making synapses with the more deeply situated second-order neurons (lamina V-VIII). Near the DREZ various types of the afferent central axons become segregated into two functionally and morphologically diverse bundles. The thick medial bundle is situated dorsomedially and comprise especially large caliber thickly myelinated $A \alpha / \beta$ fibers while thin lateral bundle is located more ventrolaterally and consists of mainly small caliber poorly-myelinated $\mathrm{A} \delta$ and unmyelinated $\mathrm{C}$ fibers.

\section{Nitric oxide and nitric oxide synthase}

Nitric oxide (NO) is highly active gaseous molecule that plays many important roles in the CNS and PNS under physiological and pathophysiological conditions. Unlike classical neurotransmitters and/or neuromodulators it is not stored in presynaptic vesicles and after 
release it does not act by influencing activity of specific presynaptic or postsynaptic membrane receptors. Rather, it diffuses freely from source of its production to neighboring structures and serves its action by activating intracellular enzyme soluble guanylyl cyclase (sGC) which in turn influences activity of different types of enzymes by second messenger molecule cyclic guanosine monophosphate (cGMP) (Jaffrey and Snyder 1995). NO is synthesized from an essential amino acid L-arginine in reaction which is catalyzed by the enzyme nitric oxide synthase (NOS) (Lowenstein and Snyder 1992). Generally, there are three different isoforms of NOS namely neuronal NOS (nNOS), endothelial NOS (eNOS) and inducible NOS (iNOS). The enzymes differ in localization pattern, way of activation and finally functional properties.

nNOS (Type I) is expressed in the different populations of central and peripheral neurons and also in some glial elements. Its synthesis is activated after binding excitatory amino acid glutamate $(\mathrm{Glu})$ to its specific postsynaptic glutamatergic receptor $N$-methyl- ${ }^{-}$ aspartate (NMDA) and subsequent opening of the ion channels which enable inflow of the extracellular calcium into the intracellular space (Bredt and Snyder 1990; Garthwaite et al. 1988).

eNOS (Type III) is found in the endothelial cells of vessels and play a key role in regulation of blood flow by relaxation of smooth muscle cells in vascular wall and subsequent vasodilatation and decrease in blood pressure. nNOS and eNOS belong to group of NOS synthases which are continuously expressed, calcium-calmodulin dependent and produce only small amount of NO (Ahern et al. 2002). However, under some pathological conditions intensity of NO production could increase and have deleterious effects (Lipton et al. 1994).

iNOS (Type II) is special type of NOS because it is not synthesized under physiological conditions and it is not dependent on calcium-calmodulin. Instead, it is produced in large uncontrolled quantities after activation of immunocompetent cells 
especially the macrophages but its expression was confirmed also in the microglia and astrocytes.

It has been well documented that NO may play a lot of different functions in the CNS and PNS under physiological and pathological conditions (Bredt and Snyder 1992; Petho and Reeh 2012). Its role is crucial in the formation of neuronal connections during development; it can act as the neuroprotective or the neurotoxic molecule during various types of neuronal injury and damage (Akira et al. 1994; Buisson et al. 1993; Leong et al. 2002); it influences release and action of other neurotransmitters and/or neuromodulators and thus participates in long-term potentiation which is necessary in processes of learning and memory (Bon and Garthwaite 2003; Johnstone and Raymond 2011; Prast and Philippu 1992). In addition, NO may play very important function in switch between neuronal proliferation and differentiation during neurogenesis (Estrada and Murillo-Carretero 2005; Gibbs 2003; Packer et al. 2003). nNOS synthesis was detected and described in detail in the SGs of different animal species using NADPH diaphorase (NADPHd) histochemical and nNOS immunocytochemical method in neurons and their processes especially in the subgroup of small- to medium-sized cell profiles (Aimi et al. 1991; Alm et al. 1995; Lazarov and Dandov 1998; Marsala et al. 2007; Radmilovich et al. 1997; Vizzard et al. 1994). None of the non-neuronal structures except of the endothelial cells of vessels exhibit nNOS expression under normal circumstances.

It has been confirmed that during early embryological development in rats and chicks almost all of the DRG neurons synthesize nNOS (Bredt and Snyder 1994; Ward et al. 1994). However, during later stages of gestation and especially after birth the synthesis of nNOS in the vast majority of DRG neurons rapidly decreases. It raises the possibility that in early stages of development when there are no contacts between the developing neurons and their target tissues the production of nNOS is high and important for the survival and 
differentiation of cells. On the other hand during the later stages of development and early postnatal period when the appropriate connections have already been established and cells are becoming dependent on peripherally produced neurotrophic factors synthesis of nNOS is gradually stopped in the majority of sensory neurons (Thippeswamy and Morris 2002).

\section{nNOSsynthesizing DRG neurons}

The most striking peculiarity of postnatal nNOS expression in the DRGs at different spinal cord levels are somewhat contradictory findings reported by different researchers in the different animal species (Table 2).

In 1991 Aimi et al. for the first time described distribution pattern of the NADPHdpositive neurons of diverse staining intensity in the nodose ganglion (NG), the TG and the DRGs at different spinal cord segments in the rat (Aimi et al. 1991). The highest percentage of NADPHd-positive cells was seen in the NG $(\sim 30 \%$ of the total cell number $)$ and this was in opposite with very low positivity in the TG $(\sim 0.3 \%)$. Concerning distribution of the NADPHd-positive neurons in the DRGs, the highest density of positive cells was found at the level of Th8-Th11 ( 20\%) and far less positivity was detected at the level of C4 and L5-S1 segments $(\sim 2 \%)$. Comparing the dorsal and ventral roots the abundant intensely stained NADPHd-positive fibers were visible in the ventral roots while relatively few positive fibers were present in the corresponding dorsal roots. Double-staining techniques revealed that most of but not all NADPHd-positive neurons exhibit calcitonin gene-related peptide immunoreactivity (CGRP-IR) and substance P immunoreactivity (SP-IR) as well, though, there were much more CGRP-IR perikarya without NADPHd-positivity. The highest NADPHd-positivity and nNOS-IR in the lower thoracic and the upper lumbar DRGs raises the possibility that these ganglionic cells are general visceral afferent neurons which has also 
been confirmed by a retrograde labelling of the afferents projecting from the gastric wall and the coeliac ganglion to the DRGs at the corresponding spinal cord segments.

Recently, Ruscheweyh et al. (2006) published data which are in accordance with results demonstrated primarily by Aimi et al. (1991). The authors employed NADPHd histochemistry and nNOS immunocytochemistry to examine lamina I projection neurons in the corresponding lumbar DRGs and observed even lower percentage $(\sim 0.7 \%)$ of nNOS-IR ganglionic cells then Aimi et al. (1991). The nNOS-IR somata were predominantly of small size and almost all of them concurrently exhibited SP-IR. Except of the above mentioned authors very low numbers of NADPHd-positive and/or nNOS-IR DRG neurons were observed also by some other researchers (Bredt and Snyder 1994; Fiallos-Estrada et al. 1993; Thippeswamy et al. 2005). On the other hand, in 1993 Terenghi et al. published data which are different from previous results (Terenghi et al. 1993). The author examined presence of nNOS in DRGs of human and rat and found that approximately $40-50 \%$ of small- to mediumsized ganglionic cells exhibited nNOS-IR.

In accordance with data published by Terenghi et al. (1993) we have observed relatively large population of nNOS-IR and NADPHd-positive largely medium-sized neurons in the midlumbar region (L3-L5) of dogs (Lukacova et al. 2006). Above L1-L2 and below L6L7 the staining intensity of nNOS-IR and NADPHd-positive profiles markedly decreased. In addition, there were many nNOS-IR and NADPHd-positive fibers of different caliber running from lateral side of the DRG as the peripheral axons to corresponding spinal nerves some of them arising directly from the immunolabeled or histochemically-stained somata. This was in opposite to the central axons emerging from the medial side of the DRG which exhibited far less nNOR-IR and NADPHd-positivity. It was interesting that the vast majority of large ganglionic cells were devoid of staining, however these were regularly encircled by the varicose nNOS-IR and NADPHd-positive fibers. 
In the sacral DRGs (S1-S3) many small- and medium-sized nNOR-IR and NADPHdpositive cells were traceable but we have also found a lower number of the large perikarya exhibiting immunoreactivity to nNOS and positivity to NADPHd. In addition, it was clear that intensity of immunolabeling and histochemical staining was virtually homogeneous in the subpopulation of small DRG neurons but in the subgroup of medium-sized ganglionic cells varied from very light hardly distinguishable from negative cells to very intense staining obscuring cell's nuclei. Further peculiarity was different pattern of distribution of both the nNOS-IR and the NADPHd-positive perikarya in the different levels of lumbar DRGs. While total number of NADPHd-positive somata was considerably higher in L1-L5 DRGs, nNORIR neurons prevailed in L6-L7 DRGs.

In the Bottlenose dolphin nNOS-IR neurons were detected in all DRGs examined (thoracic, lumbar and caudal), although with diverse distributional pattern at different spinal cord levels reaching the lowest numbers in the caudalmost ganglia (Bombardi et al. 2011). Intensity of immunostaining was similar in all DRGs and varied from moderate to strong. The nNOS-IR perikarya constituted approximately $9 \%$ of the total cell number. The vast majority of nNOS-IR neurons approximately $84 \%$ were of medium size while small and large neurons constituted only $14.9 \%$ and $1.1 \%$ respectively. Furthermore, in the population of nNOS-IR cells $81.3 \%$ also coexpress SP-IR.

Approximately $44 \%$ of all ganglionic cells in the sheep Th13 - L2 DRGs have been detected as nNOS-IR (Russo et al. 2010). The positive perikarya were evenly distributed throughout the DRGs with the largest proportion in the subpopulation of small neurons (54\%), followed by medium- (38\%) and large-sized cells $(8 \%)$. The largest proportion of DRG neurons was created by small- to medium-sized IB4-IR (79\%) perikarya from which approximately $29 \%$ were also immunoreactive for nNOS. NF200-IR somata constituted about $45 \%$ of medium- to large-sized cells but only very small percentage (4\%) of these cells 
colocalized with nNOS-IR. CGRP-IR neurons accounted for $35 \%$ of all ganglionic cells and in $15 \%$ of positive somata also nNOS-IR was detected. Finally, SP-IR DRG neurons were predominantly of small diameter and formed approximately $42 \%$ of the total neuronal pool. Double-staining method has revealed that about $10 \%$ of SP-IR cells were also nNOS-IR.

There is also a recent study which have demonstrated and confirmed larger percentage of the nNOS-containing neurons in the DRGs and support previous experiments demonstrating greater proportion of nNOS-synthesizing neurons then it was postulated by Aimi et al. (1991). Masliukov et al. (2014) examined distribution of nNOS-IR neurons in NG, Th2 and L4 DRGs in newborn to adult rats (Masliukov et al. 2014). Generally, the nNOS-IR somata were more numerous in the DRGs in comparison with the NG. The highest percentage of nNOS-IR cells was demonstrated in 1 month old rats $63.8 \%$, the lowest in newborn rats 41.3\%. In 2 month old animals it reached $52.9 \%$ and remained at later periods of ontogenesis. Furthermore, no significant differences were observed in the number of nNOS-IR somata between Th12 and L4 DRGs. Double-labeling techniques revealed that nNOS had colocalized with IB4 in $41 \%$ of newborn DRG neurons and reached approximately $90 \%$ in 10 day old rats. In the later periods of development it did not significantly change. The percentage of CGRP-IR/nNOS-IR double-labeled ganglionic cells was merely $1 \%$ in all developmental stages examined. Concerning expression of nNOS in NF200-IR ganglionic cells which are generally considered as large light cells it was highest in newborn rats $\sim 3 \%$ but decreased to $\sim 1 \%$ of positive cells in the later stages of development.

\section{Conclusion}

In conclusion, we have clearly demonstrated striking differences in the percentage of nNOS-IR and/or NADPHd-positive DRG neurons at different levels of the spinal cord in the different animal species reported by the various researchers. We should also note some 
discrepancies reported in the proportions of nNOS-IR DRG neurons which simultaneously coexpress SP, CGRP and IB4. The question arises why and to what extent we can consider these results as relevant for further research. In our opinion, there are many factors which might influence results of NADPHd histochemical and nNOS immunocytochemical identification of NO-producing structures. First of all, there are diverse primary monoclonal and polyclonal antibodies used which are produced by different companies with various sensitivity to specific neurochemical substances. Secondarily, even if there are general information about the basic histochemical and immunocytochemical protocols we know from our experience that very fine changes in the individual steps (e.g. concentration of primary antibody, duration of incubation time, temperature) may result in quite different image of stained structures and subsequent discrepancies in interpretation of the results. Furthermore, we must realize that the animals studied differ minimally in size of their bodies so it would be reasonable to assume that the size and number of neurons in defined subpopulations of small, medium- and large-sized DRG cells should differ in small animals e.g. in the rat, and in large animals e.g. in the dog or dolphin. It was published that the number of small, medium- and large-sized neurons is different even in the same animal in between the more cranially and more caudally situated DRGs, and what about the functional specializations of the individual sensory neurons at various levels of the spinal cord and in different animal species or strains. Finally, it should be stressed that there is also aspect of subjective assessment of results it means the cell with moderate or small intensity of staining is considered by one author as positive and by the others as negative. Nevertheless, there is a clear evidence that NO producing sensory neurons are present in DRGs and subserve various important functions in physiology and pathophysiology, however, we must be aware of differences presented and effort should be focused to further elucidate and explain such uncertainty. 


\section{References}

Ahern, G.P., Klyachko, V.A., and Jackson, M.B. 2002. cGMP and S-nitrosylation: two routes for modulation of neuronal excitability by NO. Trends Neurosci. 25(10): 510-517.

Aimi, Y., Fujimura, M., Vincent, S.R., and Kimura, H. 1991. Localization of NADPHdiaphorase-containing neurons in sensory ganglia of the rat. J. Comp. Neurol. 306(3): 382392. doi:10.1002/cne.903060303.

Akira, T., Henry, D., Baldwin, R.A., and Wasterlain, C.G. 1994. Nitric oxide participates in excitotoxic mechanisms induced by chemical hypoxia. Brain Res. 645(1-2): 285-290.

Alm, P., Uvelius, B., Ekstrom, J., Holmqvist, B., Larsson, B., and Andersson, K. E. 1995. Nitric oxide synthase-containing neurons in rat parasympathetic, sympathetic and sensory ganglia: a comparative study. Histochem. J. 27(10): 819-831.

Alvarez, F.J., Morris, H.R., and Priestley, J.V. 1991. Sub-populations of smaller diameter trigeminal primary afferent neurons defined by expression of calcitonin gene-related peptide and the cell surface oligosaccharide recognized by monoclonal antibody LA4. J. Neurocytol. 20(9): 716-731.

Averill, S., McMahon, S.B., Clary, D.O., Reichardt, L.F., and Priestley, J.V. 1995. Immunocytochemical localization of trkA receptors in chemically identified subgroups of adult rat sensory neurons. Eur. J. Neurosci. 7(7): 1484-1494. 
Basbaum, A.I., Bautista, D.M., Scherrer, G., and Julius, D. 2009. Cellular and molecular mechanisms of pain. Cell, 139(2): 267-284. doi:10.1016/j.cell.2009.09.028.

Bombardi, C., Cozzi, B., Nenzi, A., Mazzariol, S., and Grandis, A. 2011. Distribution of nitrergic neurons in the dorsal root ganglia of the bottlenose dolphin (Tursiops truncatus). Anat. Rec. (Hoboken), 294(6): 1066-1073. doi:10.1002/ar.21394.

Bon, C.L., and Garthwaite, J. 2003. On the role of nitric oxide in hippocampal long-term potentiation. J. Neurosci. 23(5): 1941-1948.

Bredt, D.S., and Snyder, S.H. 1990. Isolation of nitric oxide synthetase, a calmodulinrequiring enzyme. Proc. Natl. Acad. Sci. U.S A. 87(2): 682-685.

Bredt, D.S., and Snyder, S.H. 1992. Nitric oxide, a novel neuronal messenger. Neuron, 8(1): $3-11$.

Bredt, D.S., and Snyder, S.H. 1994. Transient nitric oxide synthase neurons in embryonic cerebral cortical plate, sensory ganglia, and olfactory epithelium. Neuron, 13(2): 301-313.

Buisson, A., Margaill, I., Callebert, J., Plotkine, M., and Boulu, R.G. 1993. Mechanisms involved in the neuroprotective activity of a nitric oxide synthase inhibitor during focal cerebral ischemia. J. Neurochem. 61(2): 690-696.

Estrada, C., and Murillo-Carretero, M. 2005. Nitric oxide and adult neurogenesis in health and disease. Neuroscientist, 11(4): 294-307. doi:10.1177/1073858404273850.

Fang, X., McMullan, S., Lawson, S.N., and Djouhri, L. 2005. Electrophysiological differences between nociceptive and non-nociceptive dorsal root ganglion neurones in the rat in vivo. J. Physiol. 565(Pt 3): 927-943. doi:10.1113/jphysiol.2005.086199.

Fiallos-Estrada, C.E., Kummer, W., Mayer, B., Bravo, R., Zimmermann, M., and Herdegen, T. 1993. Long-lasting increase of nitric oxide synthase immunoreactivity, NADPHdiaphorase reaction and c-JUN co-expression in rat dorsal root ganglion neurons following sciatic nerve transection. Neurosci. Lett. 150(2): 169-173. 
Garthwaite, J., Charles, S.L., and Chess-Williams, R. 1988. Endothelium-derived relaxing factor release on activation of NMDA receptors suggests role as intercellular messenger in the brain. Nature, 336(6197): 385-388. doi:10.1038/336385a0.

Gibbs, S.M. 2003. Regulation of neuronal proliferation and differentiation by nitric oxide. Mol. Neurobiol. 27(2): 107-120. doi:10.1385/MN:27:2:107.

Jaffrey, S.R., and Snyder, S.H. 1995. Nitric oxide: a neural messenger. Annu. Rev. Cell Dev. Biol. 11: 417-440. doi:10.1146/annurev.cb.11.110195.002221.

Johnstone, V.P., and Raymond, C.R. 2011. A protein synthesis and nitric oxide-dependent presynaptic enhancement in persistent forms of long-term potentiation. Learn Mem. 18(10): 625-633. doi:10.1101/lm.2245911.

Lawson, S.N., Caddy, K.W., and Biscoe, T.J. 1974. Development of rat dorsal root ganglion neurones. Studies of cell birthdays and changes in mean cell diameter. Cell Tissue Res. 153(3): 399-413.

Lazarov, N., and Dandov, A. 1998. Distribution of NADPH-diaphorase and nitric oxide synthase in the trigeminal ganglion and mesencephalic trigeminal nucleus of the cat. A histochemical and immunohistochemical study. Acta Anat. (Basel), 163(4): 191-200. doi:46498.

Leong, S.K., Ruan, R.S., and Zhang, Z. 2002. A critical assessment of the neurodestructive and neuroprotective effects of nitric oxide. Ann. N. Y. Acad. Sci. 962: 161-181.

Lipton, S.A., Singel, D.J., and Stamler, J.S. 1994. Neuroprotective and neurodestructive effects of nitric oxide and redox congeners. Ann. N. Y. Acad. Sci. 738: 382-387.

Lowenstein, C.J., and Snyder, S.H. 1992. Nitric oxide, a novel biologic messenger. Cell, 70(5): 705-707.

Lukacova, N., Kolesar, D., Marsala, M., and Marsala, J. 2006. Immunohistochemical, histochemical and radioassay analysis of nitric oxide synthase immunoreactivity in the lumbar 
and sacral dorsal root ganglia of the dog. Cell. Mol. Neurobiol. 26(1): 17-44. doi:10.1007/s10571-006-8843-4.

Marsala, J., Lukacova, N., Kolesar, D., Sulla, I., Galik, J., and Marsala, M. 2007. The distribution of primary nitric oxide synthase- and parvalbumin- immunoreactive afferents in the dorsal funiculus of the lumbosacral spinal cord in a dog. Cell. Mol. Neurobiol. 27(4): 475504. doi:10.1007/s10571-007-9140-6.

Masliukov, P.M., Emanuilov, A.I., Madalieva, L.V., Moiseev, K.Y., Bulibin, A.V., Korzina, M.B. et al. 2014. Development of nNOS-positive neurons in the rat sensory and sympathetic ganglia. Neuroscience, 256: 271-281. doi:10.1016/j.neuroscience.2013.10.013.

McCarthy, P.W., and Lawson, S.N. 1989. Cell type and conduction velocity of rat primary sensory neurons with substance P-like immunoreactivity. Neuroscience, 28(3): 745-753.

McCarthy, P.W., and Lawson, S.N. 1990. Cell type and conduction velocity of rat primary sensory neurons with calcitonin gene-related peptide-like immunoreactivity. Neuroscience, 34(3): 623-632.

Packer, M.A., Stasiv, Y., Benraiss, A., Chmielnicki, E., Grinberg, A., Westphal, H. et al. 2003. Nitric oxide negatively regulates mammalian adult neurogenesis. Proc. Natl. Acad. Sci. U. S. A. 100(16): 9566-9571. doi:10.1073/pnas.1633579100.

Petho, G., and Reeh, P.W. 2012. Sensory and signaling mechanisms of bradykinin, eicosanoids, platelet-activating factor, and nitric oxide in peripheral nociceptors. Physiol. Rev. 92(4): 1699-1775. doi:10.1152/physrev.00048.2010.

Prast, H., and Philippu, A. 1992. Nitric oxide releases acetylcholine in the basal forebrain. Eur. J. Pharmacol. 216(1): 139-140.

Radmilovich, M., Fernandez, A., and Trujillo-Cenoz, O. 1997. Localization of NADPHdiaphorase containing neurons in the spinal dorsal horn and spinal sensory ganglia of the turtle Chrysemys d'orbigny. Exp. Brain Res. 113(3): 455-464. 
Ruscheweyh, R., Goralczyk, A., Wunderbaldinger, G., Schober, A., and Sandkuhler, J. 2006. Possible sources and sites of action of the nitric oxide involved in synaptic plasticity at spinal lamina I projection neurons. Neuroscience, 141(2): 977-988. Available from http://dx.doi.org/10.1016/j.neuroscience.2006.04.010

Russo, D., Clavenzani, P., Mazzoni, M., Chiocchetti, R., Di Guardo, G., and LalattaCosterbosa, G. 2010. Immunohistochemical characterization of TH13-L2 spinal ganglia neurons in sheep (Ovis aries). Microsc. Res. Tech. 73(2): 128-139. doi:10.1002/jemt.20764.

Snider, W.D., and McMahon, S.B. 1998. Tackling pain at the source: new ideas about nociceptors. Neuron, 20(4): 629-632.

Terenghi, G., Riveros-Moreno, V., Hudson, L.D., Ibrahim, N.B., and Polak, J.M. 1993. Immunohistochemistry of nitric oxide synthase demonstrates immunoreactive neurons in spinal cord and dorsal root ganglia of man and rat. J. Neurol. Sci. 118(1): 34-37.

Thippeswamy, T., McKay, J.S., Quinn, J., and Morris, R. 2005. Either nitric oxide or nerve growth factor is required for dorsal root ganglion neurons to survive during embryonic and neonatal development. Brain Res. Dev. Brain Res. 154(2): 153-164. doi:10.1016/j.devbrainres.2004.10.011.

Thippeswamy, T., and Morris, R. 2002. The roles of nitric oxide in dorsal root ganglion neurons. Ann. N. Y. Acad. Sci. 962: 103-110.

Vizzard, M.A., Erdman, S.L., Erickson, V.L., Stewart, R.J., Roppolo, J.R., and De Groat, W.C. 1994. Localization of NADPH diaphorase in the lumbosacral spinal cord and dorsal root ganglia of the cat. J. Comp. Neurol. 339(1): 62-75. doi: 10.1002/cne.903390107.

Ward, S.M., Shuttleworth, C.W., and Kenyon, J.L. 1994. Dorsal root ganglion neurons of embryonic chicks contain nitric oxide synthase and respond to nitric oxide. Brain Res. 648(2): 249-258. Avaiable from http://dx.doi.org/10.1016/0006-8993(94)91124-X 
Zwick, M., Davis, B.M., Woodbury, C.J., Burkett, J.N., Koerber, H.R., Simpson, J.F. et al. 2002. Glial cell line-derived neurotrophic factor is a survival factor for isolectin B4-positive, but not vanilloid receptor 1-positive, neurons in the mouse. J. Neurosci. 22(10): 4057-4065. doi:20026394. 
Table 1. General classification of primary afferent fibers arising from SG neurons

\begin{tabular}{|l|l|l|l|l|l|l|}
\hline $\begin{array}{l}\text { General } \\
\text { classification }\end{array}$ & $\begin{array}{l}\text { Sensory nerve } \\
\text { classification }\end{array}$ & $\begin{array}{l}\text { Diameter } \\
(\boldsymbol{\mu m})\end{array}$ & $\begin{array}{l}\text { Conduction } \\
\text { velocity }(\mathbf{m} / \mathbf{s})\end{array}$ & Myelination & Receptors & Sensory modality \\
\hline $\mathrm{A} \alpha$ & Ia & $12-20$ & $60-120$ & $\begin{array}{l}\text { Yes } \\
\text { (thickest) }\end{array}$ & $\begin{array}{l}\text { Muscle spindle, } \\
\text { annulo-spiral } \\
\text { endings }\end{array}$ & Proprioception \\
\hline $\mathrm{A} \alpha$ & Ib & $12-20$ & $60-120$ & Yes & $\begin{array}{l}\text { Golgi tendon } \\
\text { organs }\end{array}$ & Proprioception \\
\hline $\mathrm{A} \beta$ & II & $6-12$ & $35-75$ & Yes & $\begin{array}{l}\text { Musle spindle, } \\
\text { flower-spray } \\
\text { endings, touch and } \\
\text { pressure receptors }\end{array}$ & $\begin{array}{l}\text { Superficial and } \\
\text { preessure, vibration }\end{array}$ \\
\hline $\mathrm{A} \delta$ & III & $1-5$ & $5-30$ & $\begin{array}{l}\text { Yes } \\
\text { (thinnest) }\end{array}$ & $\begin{array}{l}\text { Pain and cold } \\
\text { receptors, some } \\
\text { touch receptors }\end{array}$ & $\begin{array}{l}\text { Touch, coldness, } \\
\text { "fast pain" }\end{array}$ \\
\hline $\mathrm{C}$ & IV & $0.2-1.5$ & $0.5-2$ & No & $\begin{array}{l}\text { Pain, temperature } \\
\text { and other receptors }\end{array}$ & $\begin{array}{l}\text { Touch, warmth, } \\
\text { itch, "slow pain" }\end{array}$ \\
\hline
\end{tabular}


Table 2. The percentage of NADPHd-positive and/or nNOS-IR neurons with different cell size in the corresponding DRGs demonstrated by various authors in different animal species.

\begin{tabular}{|c|c|c|c|}
\hline Author & Animal species & $\begin{array}{c}\text { Number of NADPHd- } \\
\text { positive and/or nNOS-IR } \\
\text { neurons in corresponding } \\
\text { DRGs }\end{array}$ & Size of neurons \\
\hline Aimi et al. (1991) & Rat & $\begin{array}{c}\text { Th8-Th11 (20\%) } \\
\text { C4, L5-S1 (2\%) }\end{array}$ & Not specified \\
\hline Terenghi et al. (1993) & Rat and Men & $\begin{array}{c}40-50 \% \text { in all DRGs } \\
\text { examined }\end{array}$ & $\begin{array}{c}\text { Small to medium-sized } \\
\text { neurons }\end{array}$ \\
\hline Lukáčová et al. (2006) & Dog & $\begin{array}{c}\text { L3-L5 many } \\
\text { S1-S3 many }\end{array}$ & $\begin{array}{c}\text { Largely medium-sized } \\
\text { Russo et al. (2010) }\end{array}$ \\
\hline Bombardi et al. (2011) & Sheep & Th13-L2 (44\%) & $\begin{array}{c}\text { Predominantly small } \\
\text { neurons }\end{array}$ \\
\hline Masliukov (2014) & Rat & Th12-L4 (52,9\%) & Predominantly large-sized \\
\hline
\end{tabular}

